\title{
Present and Future Perception of Urban and Suburban Riverscapes from Drawings Made by Children and Adolescents
}

\author{
Ana Faggi ${ }^{1}$, Nora Madanes ${ }^{2}$, Virginia Diaz Villa² ${ }^{2}$ Sophie Eisenreich ${ }^{3}$, Jürgen Breuste ${ }^{3}$
}

\author{
${ }^{1}$ Flores University, Buenos Aires, ARGENTINA \\ ${ }^{2}$ Buenos Aires University, ARGENTINA \\ ${ }^{3}$ Salzburg University, AUSTRIA \\ *Corresponding Author: afaggi2003@yahoo.com.ar
}

Citation: Faggi, A., Madanes, N., Villa, V. D., Eisenreich, S., \& Breuste, J. (2021). Present and future perception of urban and suburban riverscapes from drawings made by children and adolescents. Interdisciplinary Journal of Environmental and Science Education, 17(2), e2235. https://doi.org/ $10.21601 /$ ijese/9334

\begin{tabular}{ll} 
ARTICLE INFO & ABSTRACT \\
\hline $\begin{array}{l}\text { Received: } \\
\text { 10 September 2020 }\end{array}$ & $\begin{array}{l}\text { The aim of this study is to reveal how children portray their relationships with a nearby riverscape. We } \\
\text { studied the differences in environmental perception by analyzing drawings at two scales: urban vs. } \\
\text { suburban and present state vs. future visions. A total of } 118 \text { children, aged nine to 13, were asked to draw } \\
\text { pictures of their neighboring river landscape. The elements represented were classified in four categories: } \\
\text { Accepted: }\end{array}$ \\
$\begin{array}{l}\text { biotic, abiotic, recreation and infrastructure and were analyzed using a generalized linear model. The } \\
\text { results showed that the children perceived the current landscape as a contaminated space. The elements } \\
\text { like garbage and dead animals were very relevant. The comparison between urban and suburban sectors } \\
\text { showed significant differences in the biotic and infrastructure categories, and such differences were even } \\
\text { greater between the present images and future visions. The participants had a strong attachment to } \\
\text { nature and highly valued the riverscape as a place for recreation. Research suggests a high level of interest } \\
\text { in environmental concern. }\end{array}$
\end{tabular}

Keywords: riverscape, contamination, perception, preservation, recreation, drawings

\section{INTRODUCTION}

The concept of landscape has different meanings according to the disciplines of study, but nevertheless it implies the spatial scale and humans being as important actors both throughout transformation activities or passive ones like contemplation and enjoyment. Over the course of the Anthropocene, changes in land use transformed the natural landscape and the different ways people look at it (Muñoz-Pedreros, 2018). Somehow this reflects the struggle between two divergent positions, that of the use of the landscape vs. its conservation. Regarding environmental attitudes, Bogner and Wiseman (1999) defined a two-factor Model of Environmental Values in the field of adolescent environmental perception, which was validated in different countries. This model is based on two opposing dimensions: that of the protection of the environment versus the use of natural resources for personal gain.

Urbanization is a complex and dynamic process of landscape change, increasing urban land use but also incorporating farmland, forests, wetlands, riverbanks and streams, and all kinds of nature around cities and towns into an urban pattern (Breuste \& Breuste, 2001). The urban sprawl creates a new type of landscape - the suburban landscape - with new mixtures of nature and built-up land (Johnson, 2001). In these areas nearlynatural riverbanks are frequently available but are rarely found in inner cities. Unlike inner city residents, suburban residents, and especially young people, have many more options in close proximity to use these elements of nature in multiple ways (Breuste \& Astner, 2017).

Unfortunately, urban and suburban riverscapes are often environmentally fragile as they suffer multiple alterations and impacts introduced by man (Atkinson et al., 2009). Canal regulation and riverbank interventions, land clearing, invasion of exotic plants, increase in impervious surfaces, soil and water contamination, all determine the decrease in ecosystem services and life 
quality.

Many studies refer to the environmental perception of riverscapes, showing the influence of cultural values, implications for public participation and acceptance of ecologically innovative design in rural and urban watersheds (House \& Sangster, 1991; Le Lay and RivièreHonegger, 2013; Nassauer et al., 2001).

In studies about environmental perception, traditional sociological approaches, such as surveys (Binngießer \& Randler, 2015; Bogner \& Wiseman, 1997; Perelman et al., 2012), interviews (Plieninger et al., 2013) and focus groups (Rios \& Menezes, 2017), can provide detailed information. However, perception assessment recording the presence of biodiversity and infrastructures, uses and opportunities for outdoor recreation are time consuming to carry out (Richards \& Fries, 2015). These authors proposed the use of a relatively small number of freely available, spatially explicit photographs to provide a good overview of the cultural uses of a site.

As mentioned by Sugimoto (2013) several studies of scenic perception in numerous disciplines have tried to explain the types of scenes that humans prefer in view of their visual perceptions with applicability for environment design and management. In order to evaluate actual landscapes and their elements, cognitive maps and photographs showed or taken by participants have been employed (Cherem \& Driver, 1983; Sugimoto, 2011).

It is common to use drawings to learn about children's environmental perceptions (Alerby, 2000; Barraza, 1999; Bolzan de Campos et al., 2014; Cheng \& Monroe, 2012; Hinojosa, 2013; Kalvaitis \& Monhardt, 2012; Staples et al., 2019; Liu \& Lin, 2015; Profice et al., 2015). Children's drawings are a way to understand the child's inner world. Children express their feelings, emotions, desires and concerns through their drawings and unconsciously put their concerns on paper, which is why children's drawings are used in many psychological therapies to understand what is happening (Uzunboylu \& Evram, 2017). Experts can recognize their emotions based on the size of the drawing, the style, the order and the colors used.

Freeman et al. (2015) used hand drawn mapping made by 11 year-old children with the aim of elucidate how children connect with the nearby Nature in New Zealand. Tapsell (1997) explored children's perceptions of riverscapes to gain a broader understanding of how they might participate in a sustainable management in the future.

This study focuses on child perceptions of the ecological quality of the urban and suburban riverscapes near to their homes, along a river in the Buenos Aires metropolis, Argentina.

It is noteworthy that environmental perception studies in Argentina have referred to more global approaches to the environment and are generally aimed at adults. We have not found any studies that focus on the question of the broader perception of the river as a resource / natural element, as a product and service, and that involve children, as revealed in the present study.

To fulfill the objective, we analyzed the children's drawings as we expected they would mirror their views and desires concerning the quality of the river. We expected to find perception differences in the riverscape's quality in images on a location scale (urban vs. suburban) and on a time scale (present image vs. visions for the future).

\section{MATERIAL AND METHODS}

\section{Study area}

The study area is located in the Matanza-Riachuelo river basin $\left(34^{\circ} 37^{\prime} 9.31^{\prime \prime} \mathrm{S}\right.$ and $35^{\circ} 7^{\prime} 25.07^{\prime \prime} \mathrm{S}$ and longitudes $58^{\circ} 21^{\prime} 2.06^{\prime \prime} \mathrm{W}$ and $59^{\circ} 3^{\prime} 1.21^{\prime \prime} \mathrm{W}$ ) (Figure 1). The river that runs through is a low flow plain river that has been rectified and channeled and has high levels of organic and chemical contamination (Gómez, 1999). It crosses the metropolis Buenos Aires through its most populated sector (8 million people) concentrating many industries (INDEC 2010). As stated by Guida Johnson et al. (2017) during the last century, pollution was due to industrial effluents and garbage dumped by residents into its waters. An assessment based on a riparian quality index showed bad to regular quality on the riverbanks of the urban area and regular to good conditions in the suburban area (Melignani, 2015).

\section{METHODOLOGY}

To explore the children's perception of the riparian environment we conducted a systematic approach that was subjective and inductive, based on a qualitative study to describe what the drawings showed and give them meaning. To carry out the survey in 2013 we selected urban and suburban schools located up to $1 \mathrm{~km}$ from the river to ensure that the children were familiar with the landscape (similar range of habitat types). The schools in each sector needed to be geographically and socioeconomically comparable so that children lived in similar areas (Freeman et al., 2005). The three urban schools were located in La Boca neighborhood (Buenos Aires city) and two in Avellaneda district, in the province of the Buenos Aires. In the suburban area, the four schools were located in Monte Grande and one in Cañuelas district (Table 1).

\section{Qualitative Research Design}

We visited each of the ten schools once in April. On those occasions all the children present, aged between 

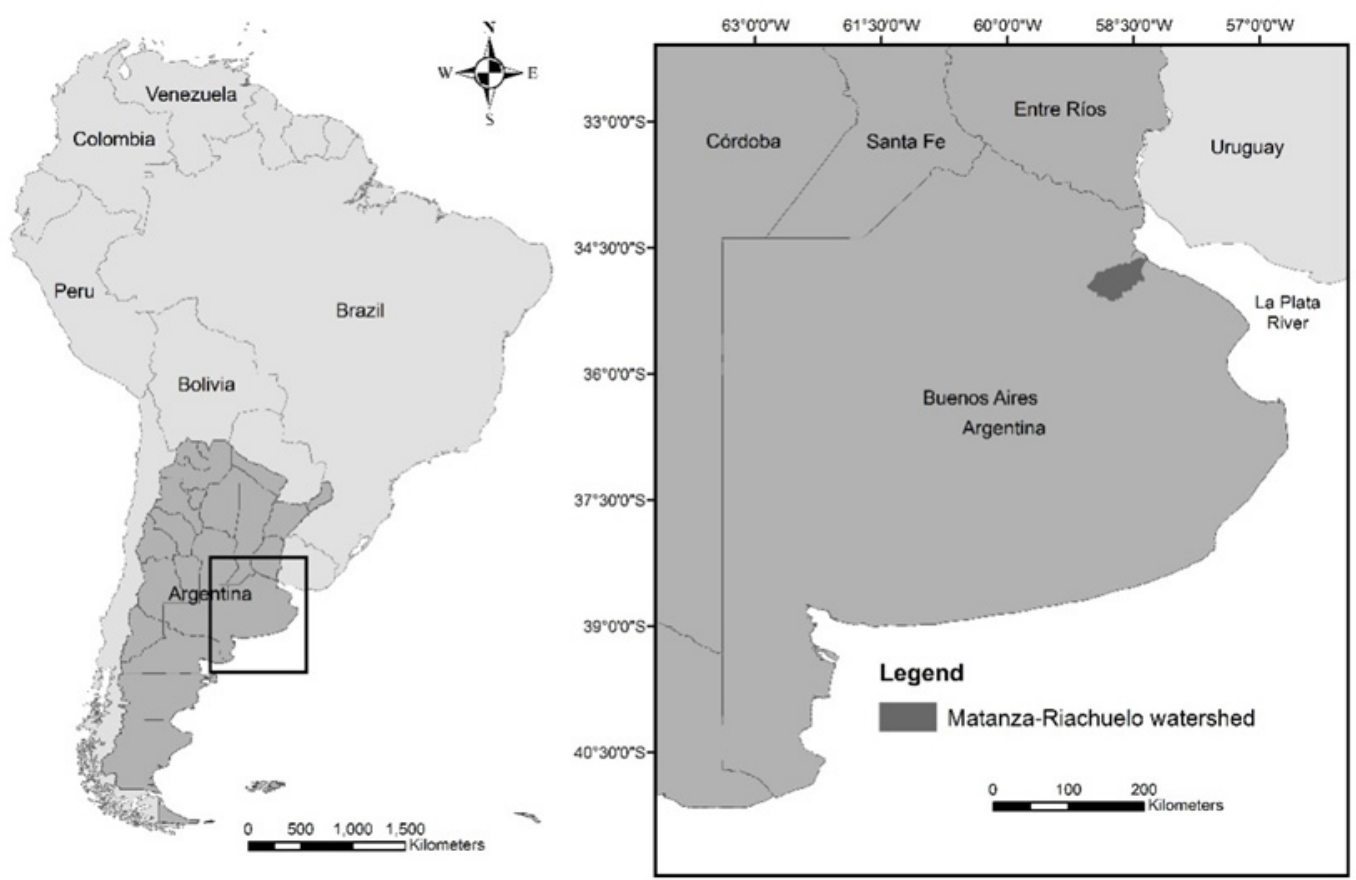

Figure 1. Location of the studied area

Table 1. Location and characteristics of schools, population density by district and number of drawing participants

\begin{tabular}{|c|c|c|c|}
\hline $\begin{array}{l}\text { Location of } \\
\text { schools }\end{array}$ & $\begin{array}{l}\text { Number of } \\
\text { participants }\end{array}$ & $\begin{array}{l}\text { Population } \\
\text { density by } \\
\text { district } \\
\text { Inhabitants } \\
\text { per sq. Km. }\end{array}$ & \\
\hline $\begin{array}{l}\text { La Boca } \\
41^{\circ} 1^{\prime} 59.4 " \mathrm{~S} \\
62^{\circ} 47^{\prime} 4.7^{\prime \prime} \mathrm{W}\end{array}$ & 42 & 8981 & URBAN \\
\hline $\begin{array}{l}\text { Avellaneda } \\
34^{\circ} 39^{\prime} 40.9^{\prime \prime} \mathrm{S} \\
58^{\circ} 22^{\prime} 6.4^{\prime \prime} \mathrm{W}\end{array}$ & 22 & 6529 & \\
\hline $\begin{array}{l}\text { Monte Grande } \\
34^{\circ} 48^{\prime} 54.2^{\prime \prime} \mathrm{S} \\
58^{\circ} 28^{\prime} 8.1^{\prime} \mathrm{W}\end{array}$ & 44 & 2508 & SUBURBAN \\
\hline $\begin{array}{l}\text { Cañuelas } \\
35^{\circ} 3^{\prime} 34.5^{\prime \prime} \mathrm{S} \\
58^{\circ} 45^{\prime} 2.3^{\prime \prime} \mathrm{Ww}\end{array}$ & 10 & 35.4 & \\
\hline
\end{tabular}

9 and 13 , were asked to make an original drawing of one scene of their nearby riverscape representing the present, and another one of their desired future (Figure 2).

We thus obtained 118 drawings, 64 from those who lived in the urban sector and 54 from the suburban area. It should be noted that the elements drawn were not prescribed by the teachers but were what the children remembered about the present or dreamt about for the future.

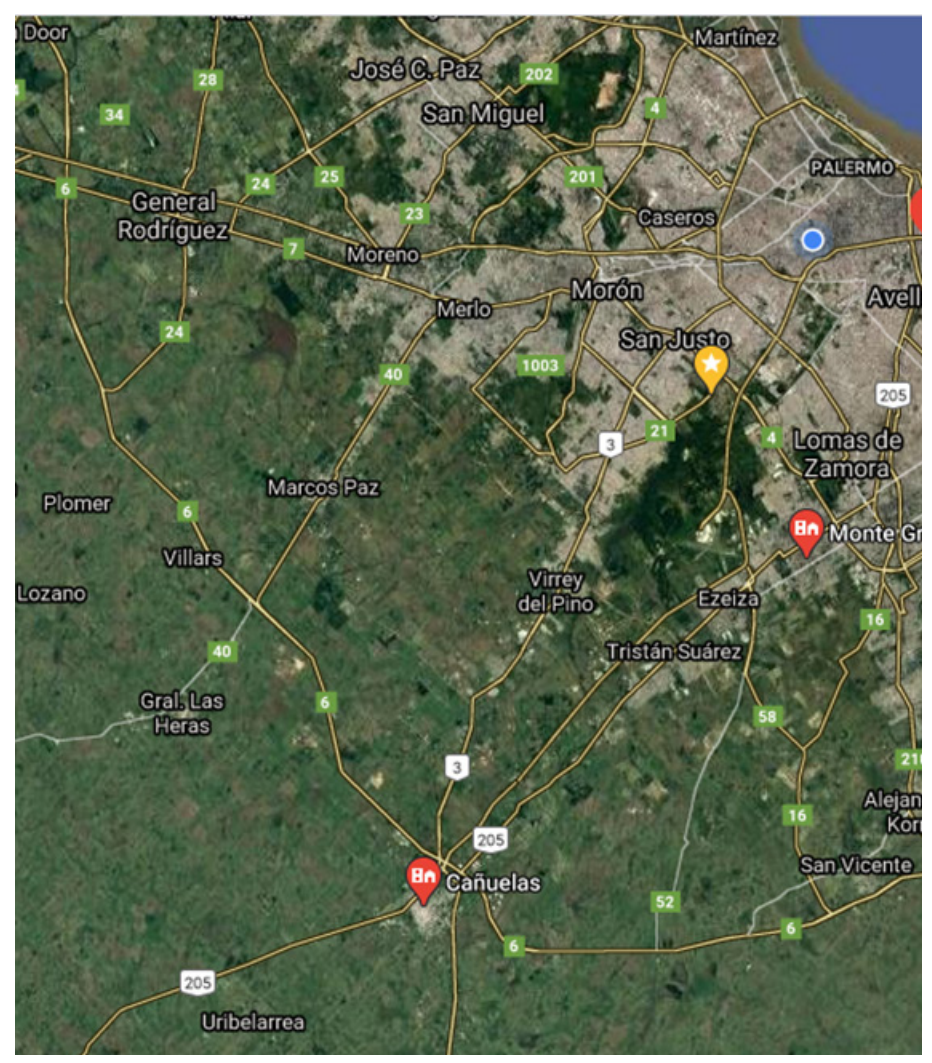

Figure 2. Selected schools located in La Boca, Avellaneda, Monte Grande and Cañuelas

One of the researchers analyzed the drawings by listing all the elements that she recognized in the drawings. Afterwards each picture was analyzed considering the frequency of the drawn elements, recognizing several factors that were arranged in four element categories: 


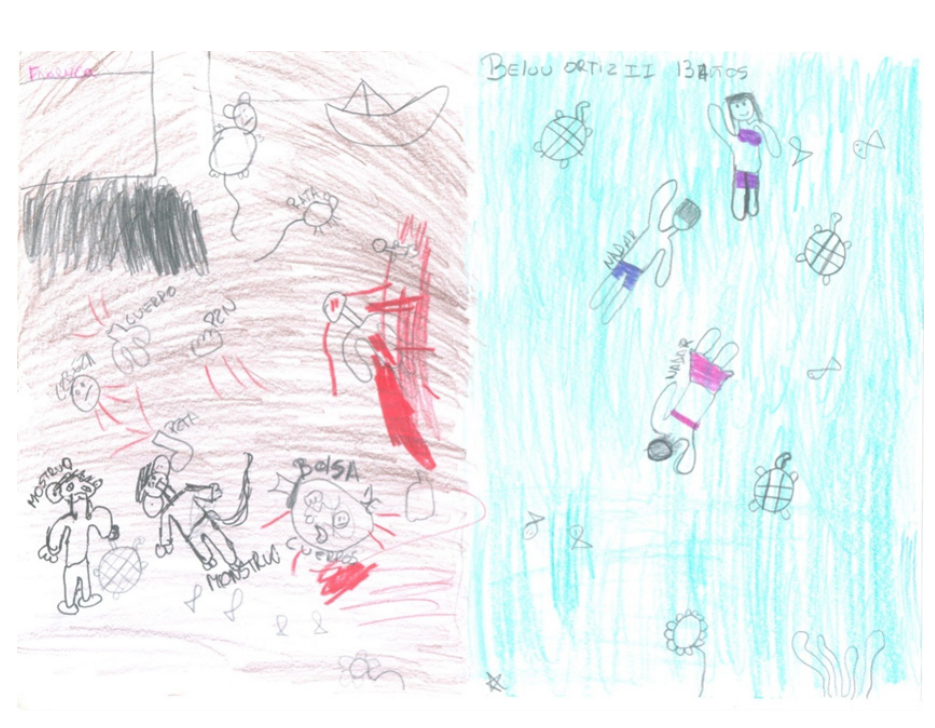

Figure 3. Drawing made by a 13-year-old urban girl. Monsters, dead people, blood, rats, trash in the current river situation in contrast to swimmers, live fish, turtles, aquatic plants and clean water in the future vision
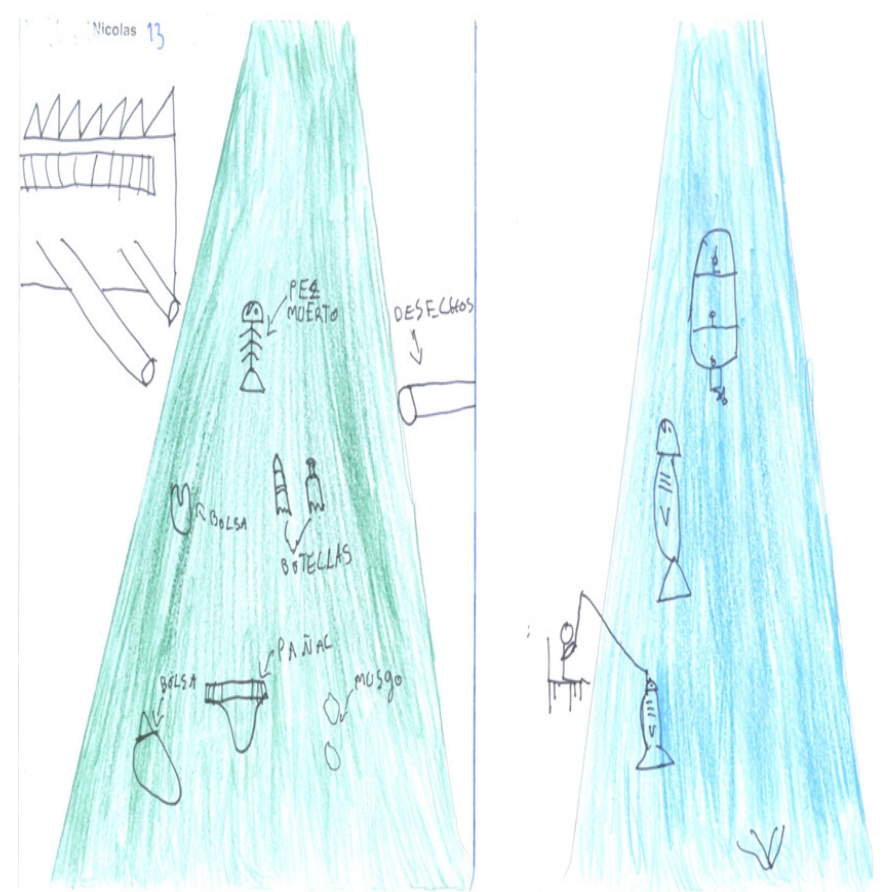

Figure 4. Drawing made by a 13-year-old boy living in the suburban area. Death, industrial effluents and dirt were drawn as opposed to the chance of fishing in the future

abiotic, biotic, recreation and infrastructure, as shown in Table 2 (Figure 3 and 4). In this study we only considered the presence of objects and not the intensity, size, or color of the drawn elements.

\section{Data Analysis}

The differences between river sections and type of drawing (present/future image) in frequency categories, as well as the frequency of each factor within the
Table 2. Categories and variables considered

\begin{tabular}{|c|c|c|c|}
\hline Abiotic & Biotic & $\begin{array}{l}\text { Recre- } \\
\text { ation }\end{array}$ & Infrastructure \\
\hline $\begin{array}{l}\text { sand, } \\
\text { garbage, } \\
\text { heaven, } \\
\text { rain, } \\
\text { clouds, } \\
\text { bad odor, } \\
\text { stones, } \\
\text { river, } \\
\text { sun }\end{array}$ & $\begin{array}{l}\text { live aquatic } \\
\text { animal, } \\
\text { dead aquatic } \\
\text { animal, } \\
\text { live terrestrial } \\
\text { animal, } \\
\text { dead terrestrial } \\
\text { animal, } \\
\text { tree, grass, } \\
\text { flowers, } \\
\text { herbs, persons, } \\
\text { dead people }\end{array}$ & $\begin{array}{l}\text { camping, } \\
\text { bikes, } \\
\text { boats, } \\
\text { resting, } \\
\text { games, } \\
\text { swim-- } \\
\text { ming, } \\
\text { fishing }\end{array}$ & $\begin{array}{l}\text { fences, seats, } \\
\text { cars, bridge, } \\
\text { streets, } \\
\text { houses, posters, } \\
\text { waste baskets, } \\
\text { sewers, build- } \\
\text { ings, } \\
\text { factory, smoke, } \\
\text { navigation, } \\
\text { navigation dock, } \\
\text { broken bridge }\end{array}$ \\
\hline
\end{tabular}

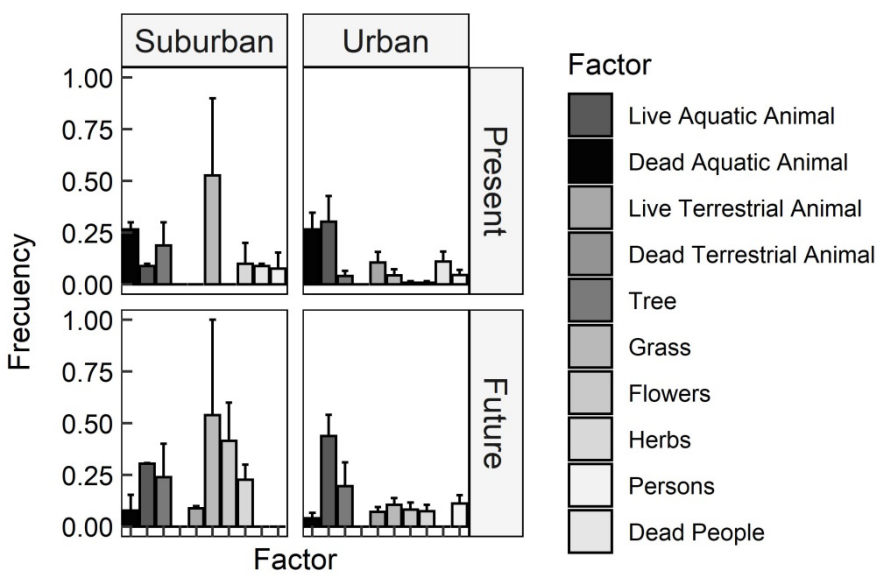

Figure 5. Relative frequency of the biotic elements

categories, were analyzed through a generalized linear model. In order to accomplish model assumptions, the frequency of drawing categories was treated as a quasibinomial variable. A backward-stepwise model selection was carried out. Starting with a three-interaction model (river section, type of drawing, category), the model was iteratively simplified until the best model was found (Zuur et al., 2009). The best model was selected based on the Akaike Information Criterion (AIC) (Akaike, 1974). Posthoc Tukey pairwise comparisons were used to analyze differences in categories and variable factors between drawings and river sections. All analyses were performed using free R software (R Core Team, 2018).

\section{RESULTS}

Figures 5, 6, 7, and 8 show the relative frequency of the recognized elements. Appendix corresponding to the four categories studied (biotic, recreation, infrastructure and abiotic) in drawings on the location and time scales.

The comparison between urban vs. suburban sectors showed significant differences in the biotic and infrastructure categories (Table 3). 


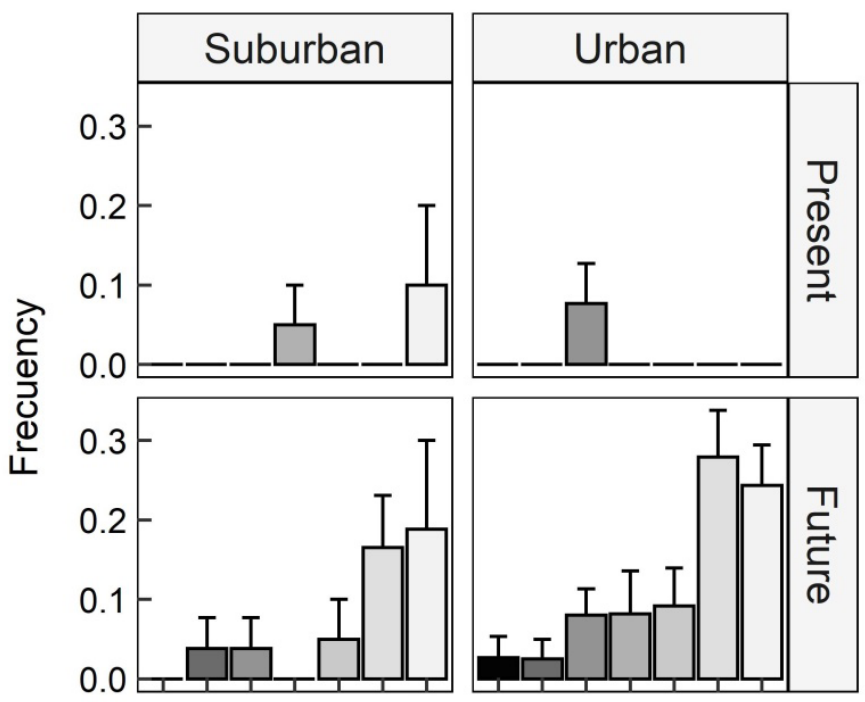

Factor

Figure 6. Relative frequency of the recreation elements

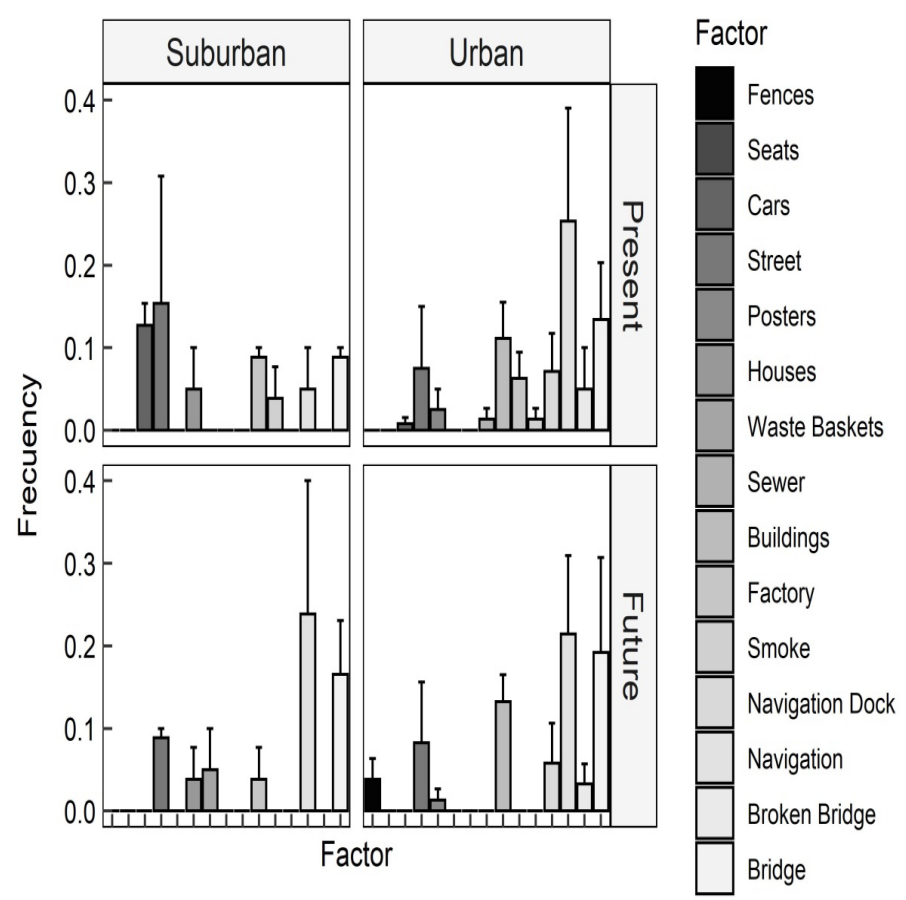

Figure 7. Relative frequency of the infrastructure elements

Elements, such as grass, flowers and herbs, were more frequently seen $(p<0.05)$ in the drawings made by children living in the suburban area, whereas fluvial transport was significant in the urban drawings. There was also a tendency for a higher frequency of garbage bins, seats, houses, cars, buildings, bridges, streets and smoke in the urban sector.

The comparisons between present images vs. desired future visions were more significant (Table 4).

Garbage frequency (paper, tires, plastic bottles, cans, burned and abandoned cars, dead animals and people thrown into the river) was higher $(P<0.05)$ in drawings mirroring the present compared to the future vision $(0.89$

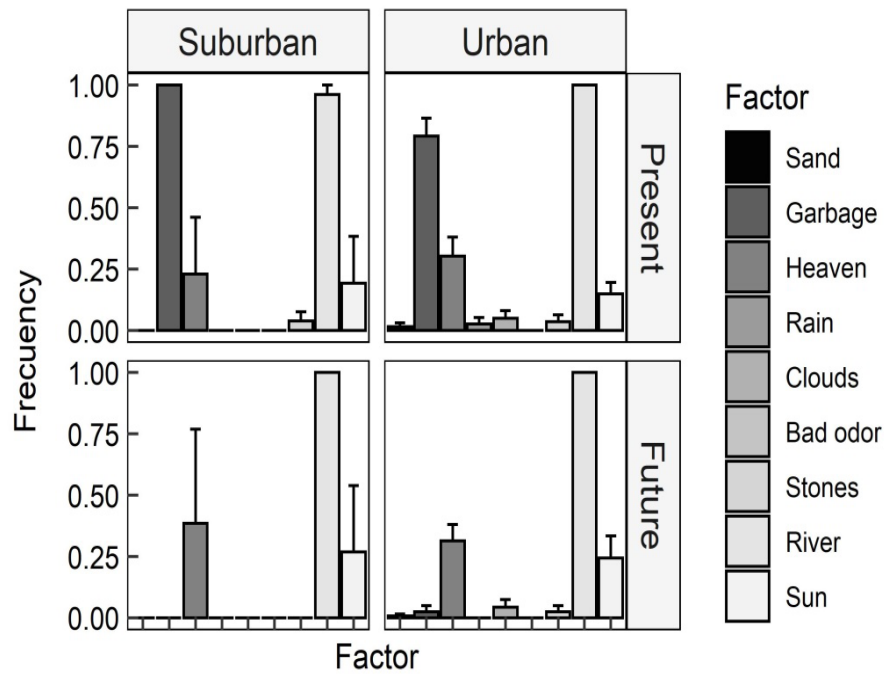

Figure 8. Relative frequency of the abiotic elements

Table 3. Significant differences recognized regarding the elements drawn in the urban and suburban areas

\begin{tabular}{ll}
\hline Abiotic & Biotic \\
No significant differences & Grass, herbs, flowers \\
\hline Infrastructure & Recreation \\
$\begin{array}{l}\text { Fluvial transport } \\
\text { Other infrastructure }\end{array}$ & No significant differences \\
\hline
\end{tabular}

Table 4. Significant differences in recognized drawn elements between the present images and desired futures visions

\begin{tabular}{ll}
\hline Abiotic & Biotic \\
Garbage & $\begin{array}{l}\text { Flowers } \\
\text { Dead aquatic animals }\end{array}$ \\
\hline Infrastructure & Recreation \\
No significant differences & Fishing and other activities \\
\hline
\end{tabular}

vs. 0.09).

In drawings representing the imagined future, garbage appeared less frequently, and the rest were similarly distributed. Dead aquatic animals appeared less frequently $(p<0.05)$ and flowers showed a higher frequency $(p<0.05)$ in the future than in the present (Table 3).

Regarding recreation, it was statiscally significant that "fishing" as a recreational activity was more frequent in the future vision drawings than in the present state. Other active recreational activities, such as swimming, playing, and camping, do not appear in the drawings of the present state.

The probability, the standard error and the asymmetry of the lower and upper limit of the variables comparisons 
between urban vs. suburban sectors and present state and future visions are shown in appendix tables (A, B,C,D).

\section{DISCUSSION}

In this study, we compared the children's perceptions of their nearby environment in the present and the expressions of their desire for an uncontaminated future by analyzing their riverscape drawings. The first drawings were used as an approach to reality through different predictors representing a cognitive dimension; vision of the future could be related to affective desires.

The results confirmed the hypotheses about finding differences in the perception of the riverscape's quality in images on a location scale and on a time scale.

Children represented the current riverscape as a contaminated space (Figure 9). The elements associated with contamination, such as all kind of garbage, dead animals, disorder and sad people, were very relevant and significantly represented in their mental images. These results differed from those found by Tavera Palomino (2015) in 7 to 12 year old children, as in Peru critical environmental problems detected by the researcher were not reflected in the children's drawings.

Our results coincided with Freeman et al. (2015) who showed that children understand well the spaces they use. Drawings of the current state mirrored the presence of garbage as an indicator of degradation similarly in the urban and the suburban sector. Grass, flowers and grasses appeared more frequently $(p<0.05)$ in the suburban sector than in the urban sector. Infrastructure factors, especially those associated with fluvial transport, were more frequently drawn in the urban sector. These differences between urban and suburban pictures reflect an urban matrix transformed by densification and by the economic activities that take place there; while the suburban landscape has a structure of more dispersed conglomerates that leave part of the natural matrix less altered. These findings are in line with Shepardson et al. (2007), who stated that urban, suburban, and rural American students drew or described natural environments in the same way, as places where plants and animals live at equal frequencies, but urban students described impacted environments more regularly than the others.

An 11 year-old boy who attended an urban school saw people in boats, drinking and throwing garbage into the river in the present. A turtle made its way with difficulty. He imagined the future river as the habitat of herons feeding on fish. A man's hand on the balustrade represents an observer looking at the scene (Figure 10).

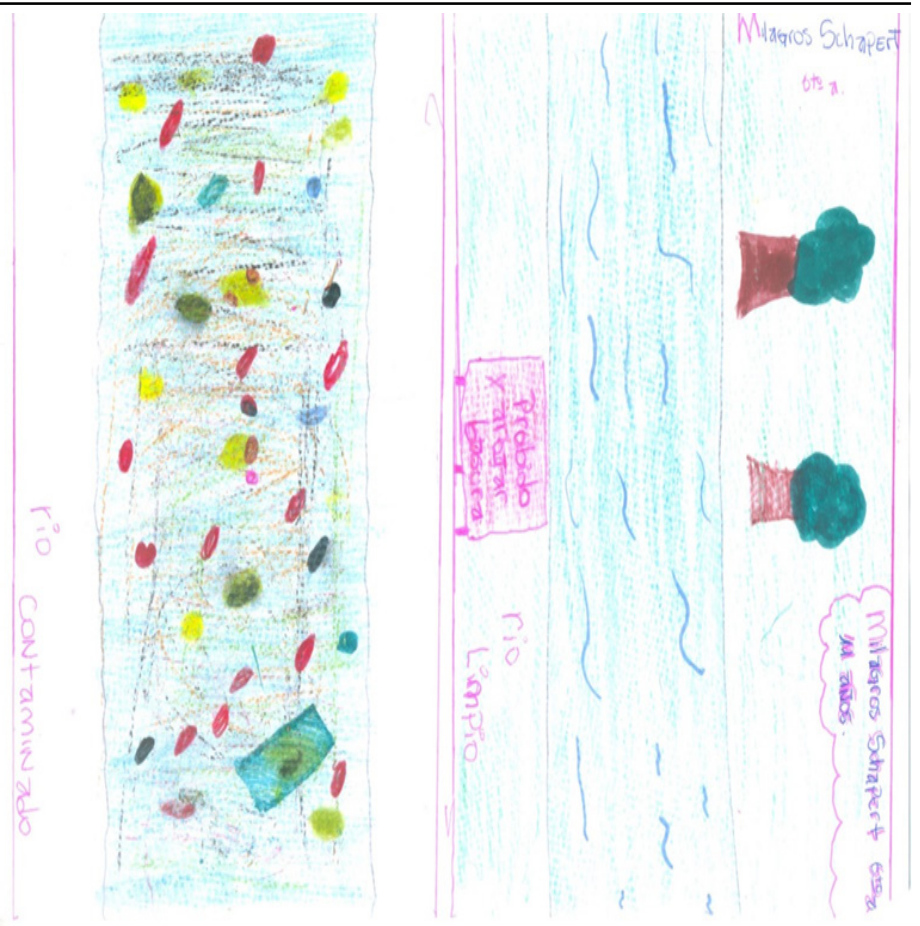

Figure 9. The river as a garbage dump and a clean and neat future. Notice a sign prohibiting to throw garbage into the river (Milagros, 11 years old girl of a suburban school)

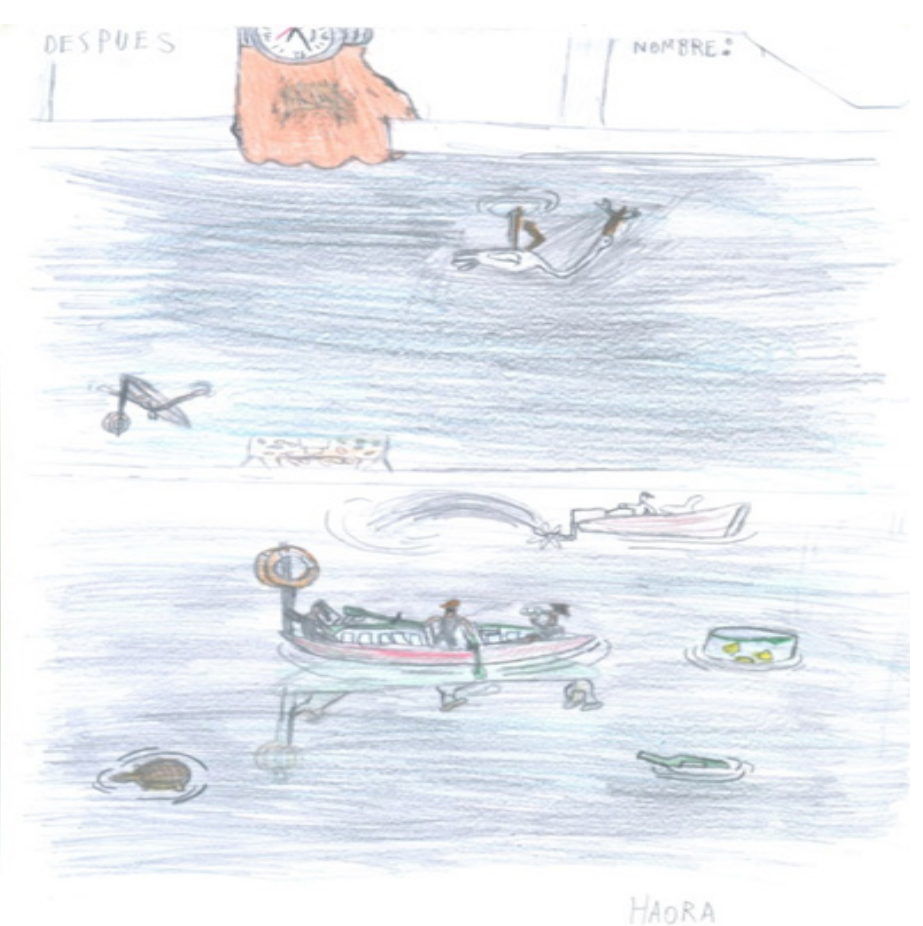

Figure 10. Franco's visions of the riverscape (11 years old, urban)

\section{Urban vs. Suburban}

We found more significant differences in environmental perceptions on the time scale (present vs. future vision) than in the location (urban vs. suburban), in coincidence with Rios and Menezes (2017), who found that children living in both urban and suburban areas had a similar 
solid emotional connection with nature that generates a strongly protective disposition. Also, Barraza (1999), analyzing drawings made by English and Mexican school children ( 7 to 9 years old), found more similarities than differences in their major concern about pollution, garbage, deforestation and expectations for the future.

Such coincidences between urban and suburban drawings are in line with the results presented by Bogner and Wiseman (1997) from a study surveying attitudinal and behavioral preferences of secondary school pupils of rural and urban residencies in Bavaria. They found that urban and suburban pupils did not differ in their verbal commitment and their reported environmental action. As stated by Alerby (2000) children's drawings showed the conflict between the good and bad, suggesting that they communicate a common sense of nature protection (Figure 11 and 12).

\section{Present State vs. Desired Future}

The desired future condition of the riverscape was drawn similarly regardless of the residence location in the watershed. The chance of fishing, plant diversity and lack of dead terrestrial and aquatic animals, together with a greater possibility of carrying out several recreational activities, were similar feelings in children from the urban and suburban schools. As stated by Cheng and Monroe (2012), Freeman et al. (2015) and Hinojosa (2013) drawings express ecocentricity, empathy with plants and animals, and also pleasure in recreating in a natural setting. A strong preference for plant diversity, including trees, is compatible with the ideal river corridor setting perceived by adults, as described by House and Sangers (1991). These results are in line with surveys carried out with adolescents from secondary schools in Leipzig (Binngießer \& Randler, 2015) that showed that pro-environmental and pro-animal attitudes are closely related.

Children's perceptions of their surroundings were also associated with the possibility of performing physical activity (Taylor et al., 2018). Our findings are in line with Tapsell (1997) who found that children had a strong concern for nature and valued outdoor space as the best place to play and explore. In our study we also found preferences for non-natural features favoring recreation (Figure 13). This drawing was made by Jaqueline, an 11-year-old girl who lives in the city of Buenos Aires, in the La Boca district. It describes how she sees the river today: a boatman crosses people from one shore to the other, rowing in a river full of garbage. The only contact people have with the river is visual; children watch the scene from an elevated bridge. She has an optimistic vision of the future, as she imagines it as clean with a diving board for diving and swimming.

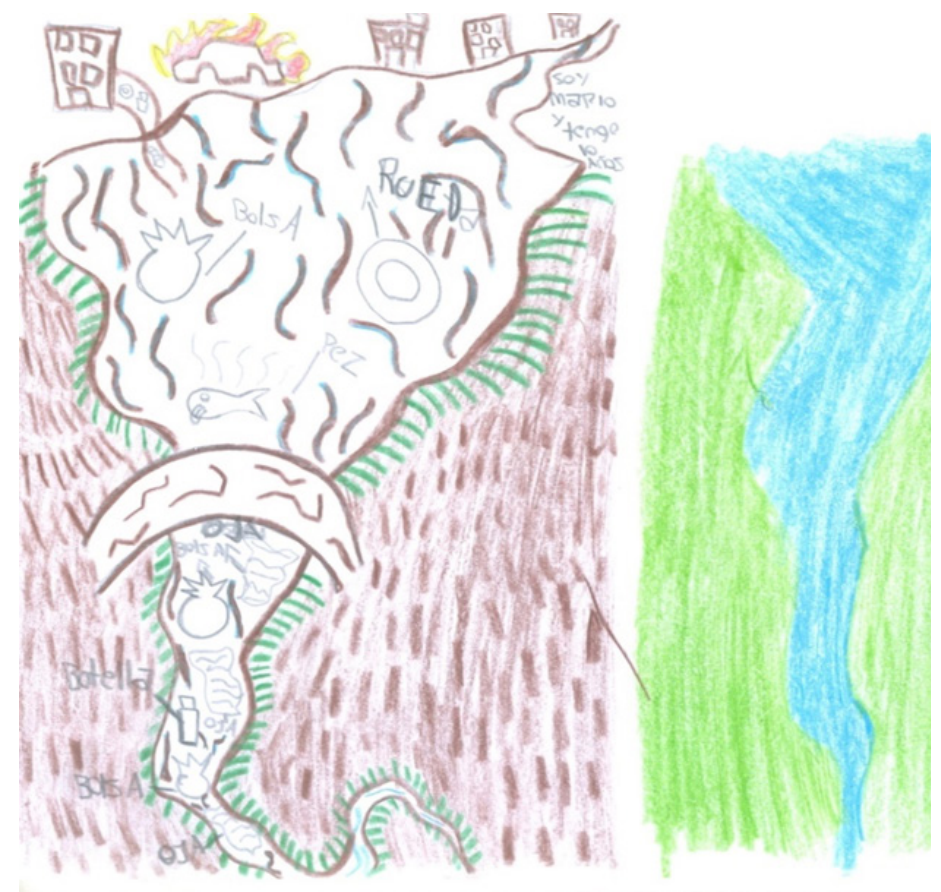

Figure 11. Mario, a 10 year-old suburban boy, summarizes the sentiment of the majority of the urban and suburban participants of this study in his drawing: disorder and death in the present vs. wellness for the future

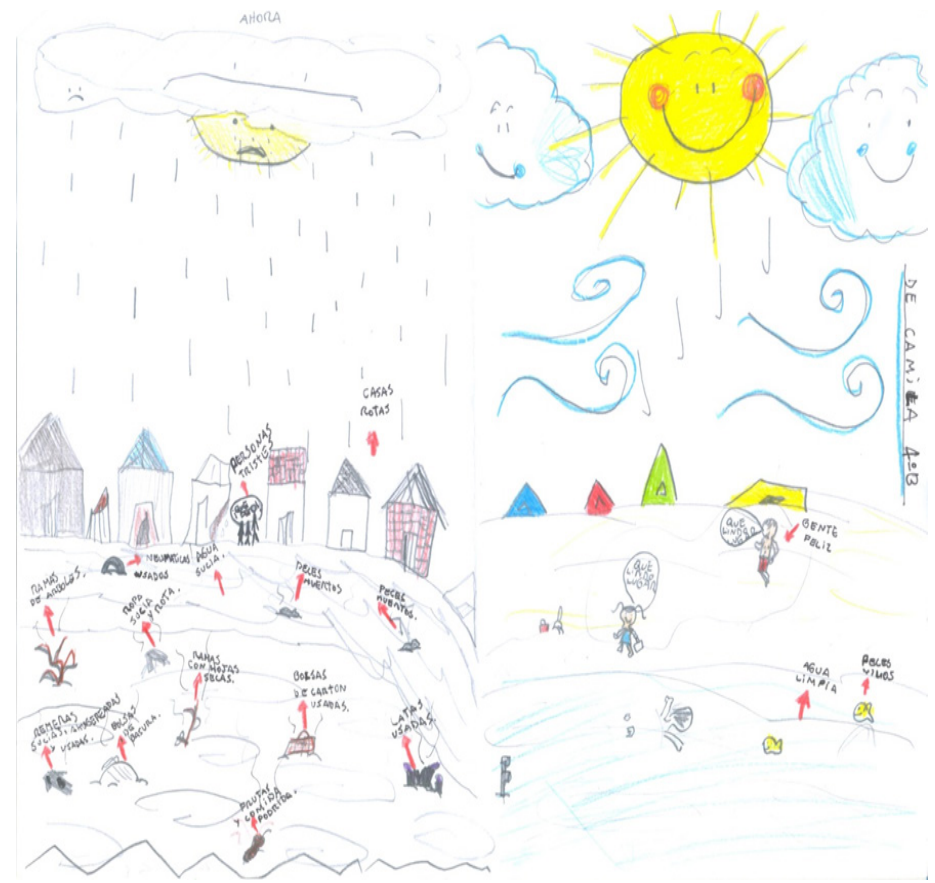

Figure 12. Camila (9 years old, urban school) drew the present with garbage of all kinds, dead fish, dirty water, broken houses, sad people and even rainy weather against a future image with happy camping people sunbathing on the beach and swimming in clean water

The possibility of fishing was statistically significant, and there was an increasing trend in sunbathing, swimming, camping, biking, etc.

Results showed a prevalence of the preservation construct over utilization (Bogner \& Wiseman, 1999). The 


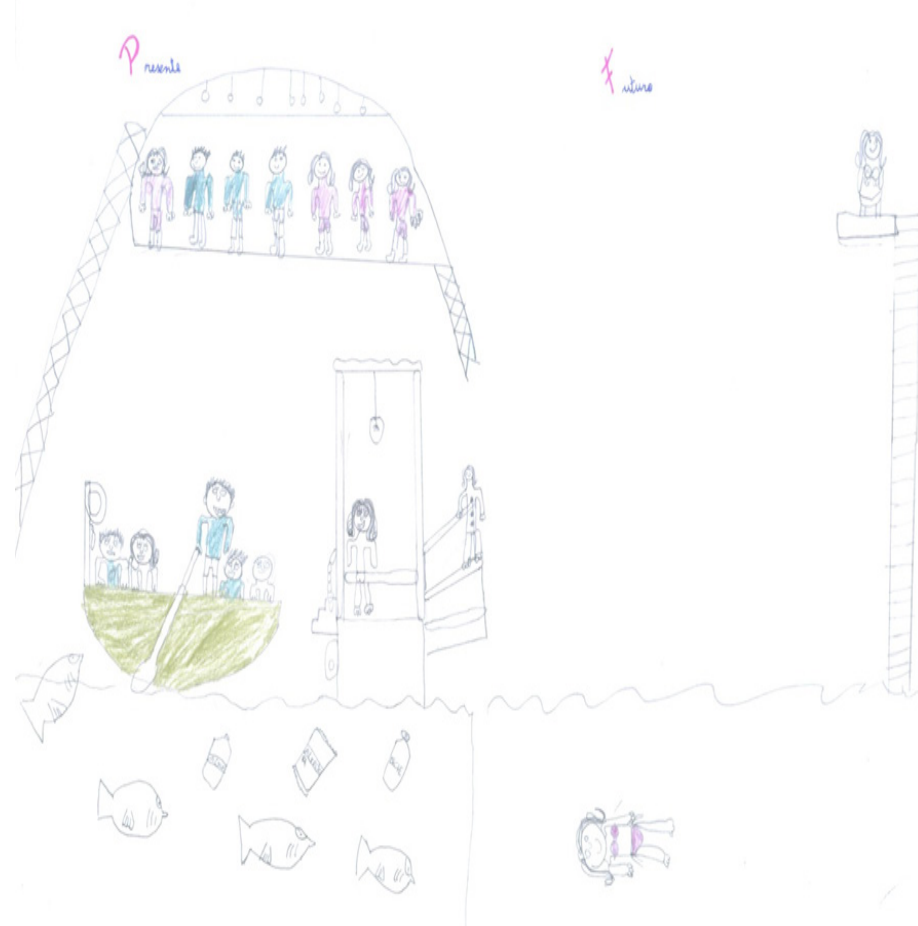

Figure 13. A drawing representing different activities at an urban river location

first one was associated with support for the preservation of animals and plants, enjoy nature and care for different resources; while exploitation was linked with different possibilities of recreational activities that the landscape could provide when it is in good condition. These differences could be because these children are between 9 and 13 years old, when playfulness is what predominates in their activities. It is also consistent with what Bogner and Wilhelm (1996) and Bogner and Wiseman (1997) stated that young scholars in general were more sensitive toward nature protection than older adolescents.

From our results it was possible to identify a similar way of representing desired nature that did not seem to be related to the place of residence. Environmental perception has to do with the way one lives in the environment and it is related to the psychosocial dimension, including cognition and affection for the environment. According to the drawings we studied, nature was associated with positive feelings of well-being and health. Similar outcomes found by Bolzan de Campos et al. (2014) in a study that aimed at knowing how children, between 8 and 12 years old from two different urban and coastal contexts, perceived and defined nature.

Research suggests a high level of interest in environmental concern, forecasting the chance for improvement as they might participate more actively in its management when they become adults.

\section{CONCLUSIONS}

The children conveyed a negative image of the present riverscape through the different abiotic, biotic, infrastructure and recreational variables that they drew, associated with death, disorder and pollution, which makes them unhappy. The river and riverbanks today are thought of as a garbage dump full of paper, plastic, flies, rats, burned cars, dead animals and people. Although there were some differences between urban and suburban environments shown by the biotic and infrastructure categories, the participants had similar wishes for the future. Urban and suburban participants wish to reverse the bad situation and to be able to use the river as a place to enjoy diverse recreational activities. They wish to contemplate a biodiverse environment where they can fish, swim, and navigate, improving their quality of life. They have a strong desire to protect the place so that they are able to use it for recreational purposes.

A popular phrase says: "One Picture is Worth a Thousand Words". The abuse of the environment threatens life on Earth. This is the desperate message left by the children's pictures. It is only through education, law observance and responsible commitment that we can reverse the impaired present.

We hope that some of the key findings will be useful to readers working in education and to those in charge of design and management of the riverscapes in Buenos Aires, to ensure that the wish for a better future comes true.

\section{REFERENCES}

Akaike, H. (1974). A new look at the statistical model identification. IEEE Transactions on Automatic Control, 19 (6), 716-723.

Alerby, E. (2000). A way of visualising children's and young people's thoughts about the environment: Study of drawings. Environmental Education Research, 6(3), 205-222. https://doi.org/ 10.1080/13504620050076713

Atkinson, C.L., Golladay, S.W., Opsahl, S.P., \& Covich, A.P. (2009). Stream discharge and floodplain connections affect seston quality and stable isotopic signatures in a coastal plain stream. Journal of the North American Benthological Society, 28(2), 360-370. doi:10.1899/08-102.1

Barraza, L. (1999). Children's drawings about the environment. Environmental Education Research, 5(1), 49-66, https://doi. org/doi: 10.1080/1350462990050103

Binngießer, J., \& Randler, C. (2015). Environmental attitudes "preservation" and"utilization" with pro-animal attitudes. International Journal of Environmental \& Science Education, 10(3), 477-492. https://doi.org/doi: 10.12973/ijese.2015.255a

Bogner, F.X., \&Wilhelm, M.G. (1996). Environmental perspectives of pupils. Development of an attitude and behavior scale. The Environmentalist, 16, 95-110. https://doi.org/10.1007/ BF01325101

Bogner, F.X., \& Wiseman, M. (1997). Environmental perception of 
rural and urban pupils. Journal of Environmental Psychology, 17, 111-122. https://doi.org/10.1006/jevp.1997.0046

Bogner, F.X., \& Wiseman, M. (1999). Toward measuring adolescent environmental perception. European Psychologist, 4(3), 139-151. https://doi.org/10.1027/10169040.4.3.139

Bolzan de Campos, C., Castellá Sarriera, J., Costa-dos-Santos, A., Bomfim, Z A., \& Fedrizzi, B. (2014). Percepción de la naturaleza por niños de contextos urbano y costero: un análisis de dibujos y palabras clave. [ Children's perception of nature from urban and coastal contexts: an analysis of drawings and keywords]. Revista Latinoamericana de Medicina Conductual / Latin American Journal of Behavioral. Medicine, 4(1), 31-40.

Breuste, J., \& Astner, A. (2017). Which kind of nature is liked in urban context? A case study of SolarCity Linz, Austria. Mitteilungen der Österreichischen Geographischen Gesellschaft, 159, 105-129. https://doi.org/doi: 10.1553/ moegg159s1

Breuste, J., \& Breuste, I. (2001), Stadtnaturschutz - theoretische Positionen und empirische Befunde zur Nutzung und Akzeptanz von Pflegegrün und Wildnatur in der Stadt Halle/ Saale [Urban nature protection - theoretical positions and empirical findings on utilisation and acceptance of maintained green and wilderness in the city Halle/ Saale]. In: Geobotanisches Kolloquium, 16, pp. 25-36. Bundesminsterium für Umwelt.

Cheng, J., \& Monroe, M. (2012). Connection to Nature: Children's Affective Attitude Toward Nature. Environment and Behavior - Environmental Behavoir, 44, 31-49. https:// doi.org/doi: 10.1177/0013916510385082

Cherem, G. J., \& Driver, B. L. (1983). Visitor employed photography: A technique to measure common perceptions of natural environments. Journal of Leisure Research, 15(1), 65-83. https://doi.org/10.1080/00222216.1983.11969541

Freeman, C., van Heezik, Y., Stein, A., \& Hand, K. (2015). Natural Neighbourhoods for city children: Report on Research Findings University of Ontago, Dunedin ISBN 978-0-473-3

Gómez, N. (1999). Epipelic diatoms from the MatanzaRiachuelo river (Argentina), a highly polluted basin from the pampean plain: Biotic indices and multivariate analysis. Aquatic Ecosystem Health \& Management, 2(3), 301-309, DOI: 10.1080/146349899086569661872-7. p. 55

Guida-Johnson, B., Faggi, A. M., \& Zuleta, G. A. (2017). Effects of Urban Sprawl on Riparian Vegetation: Is Compact or Dispersed Urbanization Better for Biodiversity? River Research and Applications, 33(6), 959-969 https://doi. org/10.1002/rra.3138

Hinojosa, M. (2013). Percepciones de los niños de la zona de amortiguamiento del Parque Nacional Cerros de Amotape acerca del bosque aledaño [Perceptions of children in the buffer zone of the Cerros de Amotape National Park about the neighboring forest] Revista Latinoamericana de Medicina Conductual, 25, 137-156.

House, M A., \& Sangster, E. K. (1991). Public perception of RiverCorridor management. Water and Environment, 5, 312-316. https://doi.org/10.1111/j.1747-6593.1991.tb00624.x.

Johnson, M.P. (2001). Environmental impacts of urban sprawl: A survey of the literature and proposed research agenda. Environment and Planning A: Economy and Space, 33, 717-
735. doi:10.1068/a3327.

Kalvaitis, D., \& Monhardt, R. M. (2012). The architecture of children's relationships with nature: a phenomenographic investigation seen through drawings and written narratives of elementary students, Environmental Education Research, 18(2), 209-227, https://doi.org/: 10.1080/13504622.2011.598227.

Le Lay, Y.F., Piégay, H., \& Rivière-Honegger, A. (2013). Perception of braided river landscapes: Implications for public participation and sustainable management, Journal of Environmental Management, 119, 12.https://doi. org/10.1016/j.jenvman.2013.01.006,

Liu, S.C., \& Lin, H.S. (2015) Exploring undergraduate students' mental models of the environment: Are they related to environmental affect and behavior? The Journal of Environmental Education, 46(1), 23-40, https://doi.org/: 10.1080/00958964.2014.953021

Melignani, E. (2015). Índice de Calidad de Ribera [Riverbank quality index] In Faggi A. \& Breuste J. (Eds.), La cuenca Matanza-Riachuelo: una mirada ambiental para recuperar sus riberas (pp.22-30). Universidad de Flores.

Muñoz-Pedreros, A. (2018). El paisaje virtual un recurso importante y pobremente conservado. [Virtual landscape an important resource poorly conserved] Health and Place. 54, 221-228.https://doi.org/10.1016/10.002.

Nassauer, J. I., Kosek, S. E. \& Corry, R. C. (2001). Meeting public expectations with ecological innovation in Riparian landscapes. Journal of the American Water Resources Association, 37(6), 1439-1443, https://doi.org/ 10.1111/ j.1752-1688.2001.tb03650.x

Perelman, P., Breuste, J., Madanes, N., Gropper, C., Melignani, E., \& Faggi, A. (2012). Use of visitors' perception in urban reserves in the Buenos Aires metropolis. Urban Ecosystems. https://doi.org/ 10.1007/s11252-012-0279-7

Plieninger, T., Dijks, S., Oteros-Rozas, E., \& Bieling, C. (2013). Assessing, mapping, and quantifying cultural ecosystem services at community level. Land Use Policy. 33. 118-129. 10.1016/j.landusepol.2012.12.013

Profice, C., Pinheiro, J. Q., Fandi, A. C., \& Gome, A. R. (2015). Children's environmental perception of protected areas in the Atlantic Rainforest PsyEcology. Revista Bilingüe de Psicología Ambiental / Bilingual Journal of Environmental Psychology, 6(3), 328-358.

R Core Team. (2018). R: A language and environment for statistical computing. $\mathrm{R}$ Foundation for Statistical Computing, Vienna, Austria. URL: https://www.R-project. org/.

Richards, D.R., \& Fries, D. A. (2015). A rapid indicator of cultural ecosystem service usage at a fine spatial scale: Content analysis of social media photographs Department. Ecological Indicators, 53, 187-195

Rios, C., \& Menezes, I. (2017). I saw a magical garden with flowers that people could not damage!': Children's visions of nature and of learning about nature in and out of school, Environmental Education Research, 23(10), 1402-1413, https://doi.org/10.1080/13504622.2017.1325450

Shepardson, D.P., Wee, B., Priddy, M., \& Harbor, J. (2007). Students' mental models of the environment, Journal of Research in Science Teaching, 44, 327-348. https://doi. org/10.1002/tea.20161 
Staples, A.F., Larson, L.R., Worsley, T.E., Green, G. T., \& Carroll, J. P. (2019). Effects of an art-based environmental education camp program on the environmental attitudes and awareness of diverse youth. The Journal of Environmental Education, 50(3), 208-222, https://doi.org/10.1080/0095896 4.2019.1629382

Sugimoto, K. (2011). Analysis of scenic perception and its spatial tendency: Using digital cameras, GPS loggers, and GIS. Procedia-Social and Behavioral Sciences, 21, 43-52. https:// doi.org /10.1016/j.sbspro.2011.07.010

Sugimoto, K. (2013). Quantitative measurement of visitors' reactions to the settings in urban parks: Spatial and temporal analysis of photographs. Landscape and Urban Planning 110, 59- 63. https://doi.org/10.1016/j.landurbplan.2012.10.004

Tapsell, S. M. (1997). Rivers and river restoration: A child's-eye view, Landscape Research, 22(1), 45-65, https://doi.org/: $10.1080 / 01426399708706500$

Tavera Palomino, M. (2015). Percepción ambiental y prácticas en el espacio geográfico de los niños y niñas de 7 a 12 años del asentamiento humano del pueblo libre, Distrito de Belén, Provincia de Maynas, Departamento de Loreto, Perú. Facultad de Ciencias y Letras Humanas. Pontificia Universidad Católica del Perú [Environmental perception and practices in the geographical space of boys and girls from 7 to 12 years of age in the human settlement of the free people, District of Belén, Province of Maynas, Department of Loreto, Peru] http://hdl.handle.net/20.500.12404/6488

Taylor, L. G., Clark, A. F., \& Gilliland, J. A. (2018).Context matters: Examining children's perceived barriers to physical activity across varying Canadian environments . Health \& Place, 54, 221-228. https://doi.org/10.1016/j.healthplace.2018.10.002

Uzunboylu, H., \& Evram, G. (2017). Understanding children's paintings in psychological counseling with children. New Trends and Issues Proceedings on Humanities and Social Sciences, 3, 449-463. https://doi.org: 10.18844/gjhss. v3i3.1621

Zuur, A., Leno, E. N., Walker, N., Saveliev, A. A., \& Smith, G. M. (2009). Mixed effects models and extensions in ecology with R. Springer Science \& Business Media. (pp574). ISBN 978-0387-87458-6 
APPENDIX. Relative frequencies of the drawn elements in the suburban and urban areas in the present state and future vision

\begin{tabular}{|c|c|c|c|c|}
\hline & Suburban & Suburban & Urban & Urban \\
\hline & Present & Future & Present & Future \\
\hline \multicolumn{5}{|l|}{ Abiotic } \\
\hline sand & 0.0 & 0.0 & 0.01 & 0.09 \\
\hline garbage & 1.0 & 0.01 & 0.78 & 0.17 \\
\hline heaven & 0.12 & 0.20 & 0.3 & 0.37 \\
\hline rain & 0.0 & 0.0 & 0.03 & 0.0 \\
\hline clouds & 0.0 & 0.01 & 0.05 & 0.05 \\
\hline bad odor & 0.1 & 0.0 & 0.0 & 0.0 \\
\hline stones & 0.01 & 0.0 & 0.04 & 0.05 \\
\hline river & 0.98 & 1.0 & 1.0 & 1.0 \\
\hline sun & 0.1 & 0.14 & 0.15 & 0.24 \\
\hline \multicolumn{5}{|l|}{ Biotic } \\
\hline dead aquatic animal & 0.18 & 0.1 & 0.27 & 0.04 \\
\hline live aquatic animal & 0.13 & 0.2 & 0.30 & 0.43 \\
\hline tree & 0.21 & 0.3 & 0.04 & 0.20 \\
\hline dead terrestrial animal & 0.03 & 0.0 & 0.0 & 0.0 \\
\hline live terrestrial animal & 0.01 & 0.05 & 0.11 & 0.26 \\
\hline grass & 0.48 & 0.32 & 0.04 & 0.10 \\
\hline flowers & 0.0 & 0.27 & 0.008 & 0.08 \\
\hline herbs & 0.05 & 0.16 & 0.008 & 0.08 \\
\hline dead people & 0.04 & 0.01 & 0.11 & 0.0 \\
\hline persons & 0.06 & 0.13 & 0.05 & 0.11 \\
\hline \multicolumn{5}{|l|}{ Infrastructure } \\
\hline fences & 0.0 & 0.0 & 0.0 & 0.04 \\
\hline seats & 0.01 & 0.01 & 0.0 & 0.0 \\
\hline cars & 0.26 & 0.04 & 0.01 & 0.0 \\
\hline streets & 0.08 & 0.01 & 0.08 & 0.08 \\
\hline posters & 0.0 & 0.05 & 0.03 & 0.01 \\
\hline houses & 0.04 & 0.02 & 0.0 & 0.0 \\
\hline waste baskets & 0.01 & 0.01 & 0.0 & 0.0 \\
\hline sewers & 0.0 & 0.0 & 0.01 & 0.0 \\
\hline buildings & 0.02 & 0.01 & 0.11 & 0.13 \\
\hline factory & 0.1 & 0.04 & 0.06 & 0.0 \\
\hline smoke & 0.02 & 0.0 & 0.01 & 0.0 \\
\hline navigation dock & 0.0 & 0.0 & 0.07 & 0.06 \\
\hline navigation & 0.0 & 0.03 & 0.21 & 0.21 \\
\hline broken bridge & 0.0 & 0.0 & 0.05 & 0.03 \\
\hline bridge & 0.18 & 0.21 & 0.13 & 0.19 \\
\hline \multicolumn{5}{|l|}{ Recreation } \\
\hline camping & 0.0 & 0.02 & 0.0 & 0.03 \\
\hline bikes & 0.04 & 0.36 & 0.0 & 0.03 \\
\hline boats & 0.0 & 0.02 & 0.08 & 0.08 \\
\hline resting & 0.02 & 0.01 & 0.0 & 0.08 \\
\hline games & 0.0 & 0.05 & 0.0 & 0.09 \\
\hline swimming & 0.0 & 0.01 & 0.0 & 0.28 \\
\hline fishing & 0.04 & 0.18 & 0.0 & 0.24 \\
\hline
\end{tabular}

